$$
50^{\circ}
$$

SERI/TP-731-626
April 1980

\section{The Use of Solar Energy to Produce Process Heat for Industry}

Ken Brnwn
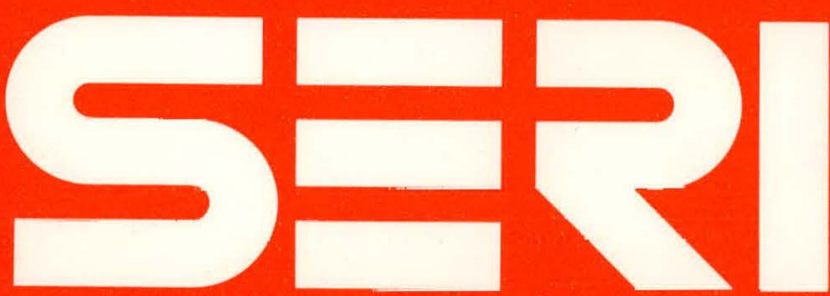

Solar Energy Research Institute

A Division of Midwest Research Institute

1617 Cole Boulevard

Golden, Colorado 80401

Operated for the

U.S. Department of Energy

under Contract No. EG-77-C-01-4042 


\section{DISCLAIMER}

This report was prepared as an account of work sponsored by an agency of the United States Government. Neither the United States Government nor any agency Thereof, nor any of their employees, makes any warranty, express or implied, or assumes any legal liability or responsibility for the accuracy, completeness, or usefulness of any information, apparatus, product, or process disclosed, or represents that its use would not infringe privately owned rights. Reference herein to any specific commercial product, process, or service by trade name, trademark, manufacturer, or otherwise does not necessarily constitute or imply its endorsement, recommendation, or favoring by the United States Government or any agency thereof. The views and opinions of authors expressed herein do not necessarily state or reflect those of the United States Government or any agency thereof. 


\section{DISCLAIMER}

Portions of this document may be illegible in electronic image products. Images are produced from the best available original document. 
Printed in the Uniter States of A merica

Available from:

National Technical Information Service

U.S. Department of Commerce

5285 Port Royal Road

Springfield, VA 22161

Price:

Microfiche $\$ 3.00$

Printed Copy $\$ 4.00$

\begin{abstract}
NOTICE
This report was prepared as an account of work sponsored by the United States Government. Neither the United States nor the United States Department of Energy, nor any of their employees, nor any of their contractors, subcontractors, or their employees, makes any warranty, express or implied, or assumes any legal liability or responsibility for the accuracy, completeness or usefulness of any information, apparatus, product or process disclosed, or represents that its use would not infringe privately owned rights.
\end{abstract}




$$
\begin{aligned}
& \text { SERI /TP }-731-626 \\
& \text { UC CATEOGRY \& UC-62a,b,c }
\end{aligned}
$$

THE USE OF SOLAR ENERGY TO

PRODUCE PROCESS HEAT FOR

INDUSTRY

\section{KEN BROWN}

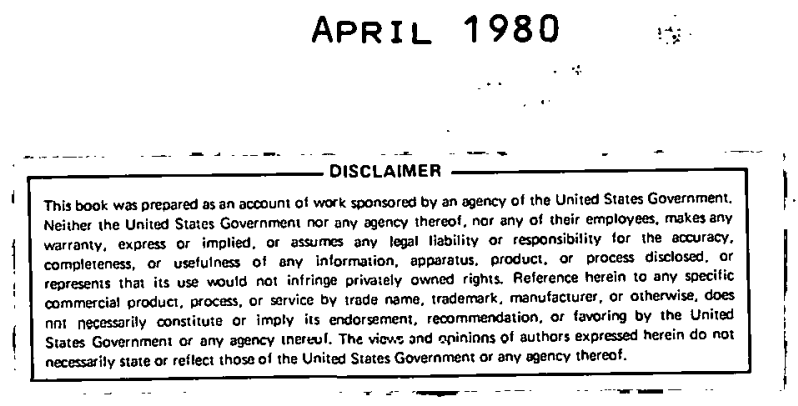

PREPARED UNDER TASK No. 3473.30

\section{Solar Energy Research Institute}

1536 Cole Boulevard

Gulden, Colorado 80401

A Division of Midwest Research Institute

Prepared for the

U.S. Department of Energy

Contract No. EG $\cdot 77 \cdot \mathrm{C} \cdot 01 \cdot 4042$

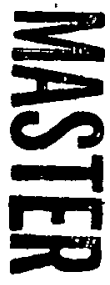




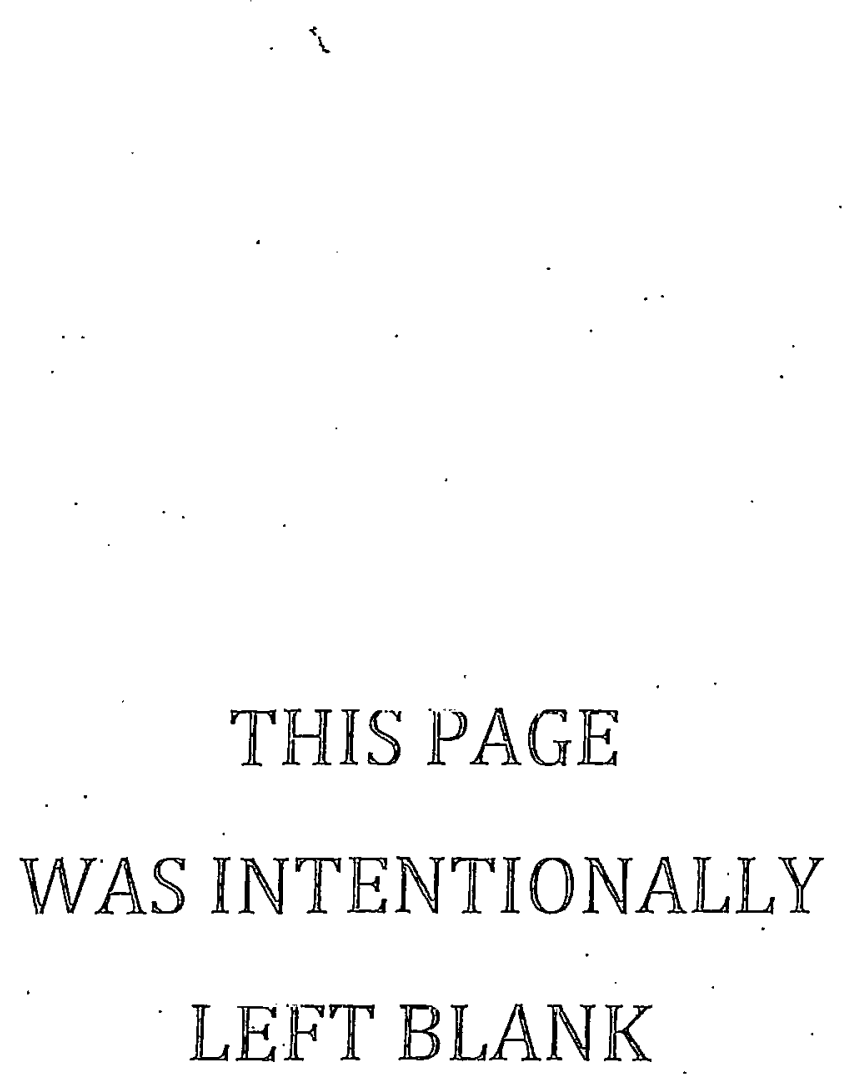




\section{FOREWORD}

This paper was prepared as an invited presentation to the 30th Annual National Plant Engineering and Maintenance Conference in Chicago, minois. The presentation was made in a session entitled "The Solar Transition." Interest in the subject of energy conservation and renewable energy is almost universal among today's plant engineers, and it is particularly appropriate that time should have been given to the discussion of the role of solar thermal energy as industry begins a new decade.

Information contained in this paper has been generated from work performed in Task 3472 (Engineering Field Test Evaluation) and in Task 3473.30 (Solar IPH Cost and Cost Goal Analysis). We gratefully recognize the contributions of $\mathrm{Mr}$ : E. Kenneth May and Mr. Charles Kutscher who have contributed greatly to the understanding of industrial applications and of solar thermal IPH systems, respectively, through their work at the Solar Energy Research Institute.

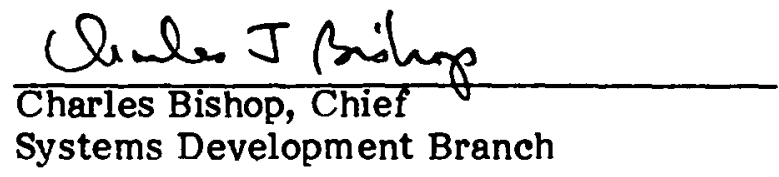

Approved for:

SOLAR ENERGY RESEARCH INSTITUTE

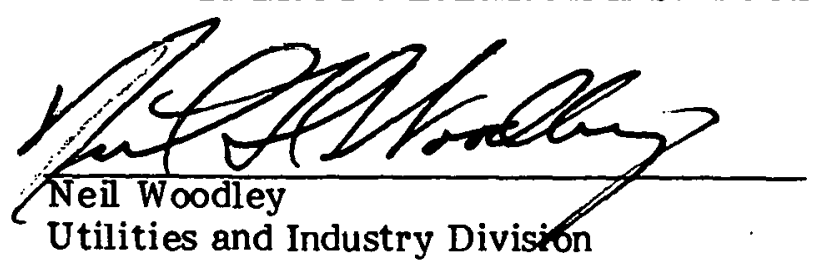


THIS PAGE

WAS INTENTIONALLY

LEFT BLANK 


\section{SUMMARY}

The role of solar energy in supplying heat and hot water to residential and commercial buildings is familiar to many of us. On the other hand, the role that solar energy may play in displacing imported energy supplies in the industrial and utility sectors of ten goes unrecognized. The versatility of solar technology lends itself well to applications in industry; particularly to the supplemental supply of process heat of all kinds.

The realization of that potential will depend, however, on the identification of the most suitable applications and locations for industrial solar energy and the continued improvement in cost, durability, and reliability of solar equipment. The status of solar thermal technology for industrial process heat applications is surveyed in this paper, including a description of current costs and operating histories. Because the current status is unsatisf actory in view of the goals established by President Carter for solar industrial energy, this paper outlines the most important objectives to be met in improving system perf orm ance, reducing cost, and identifying markets for solar IPH. The effect of government tax policy will be of little impact until technical efficiency and cost effectiveness are significantly improved. 


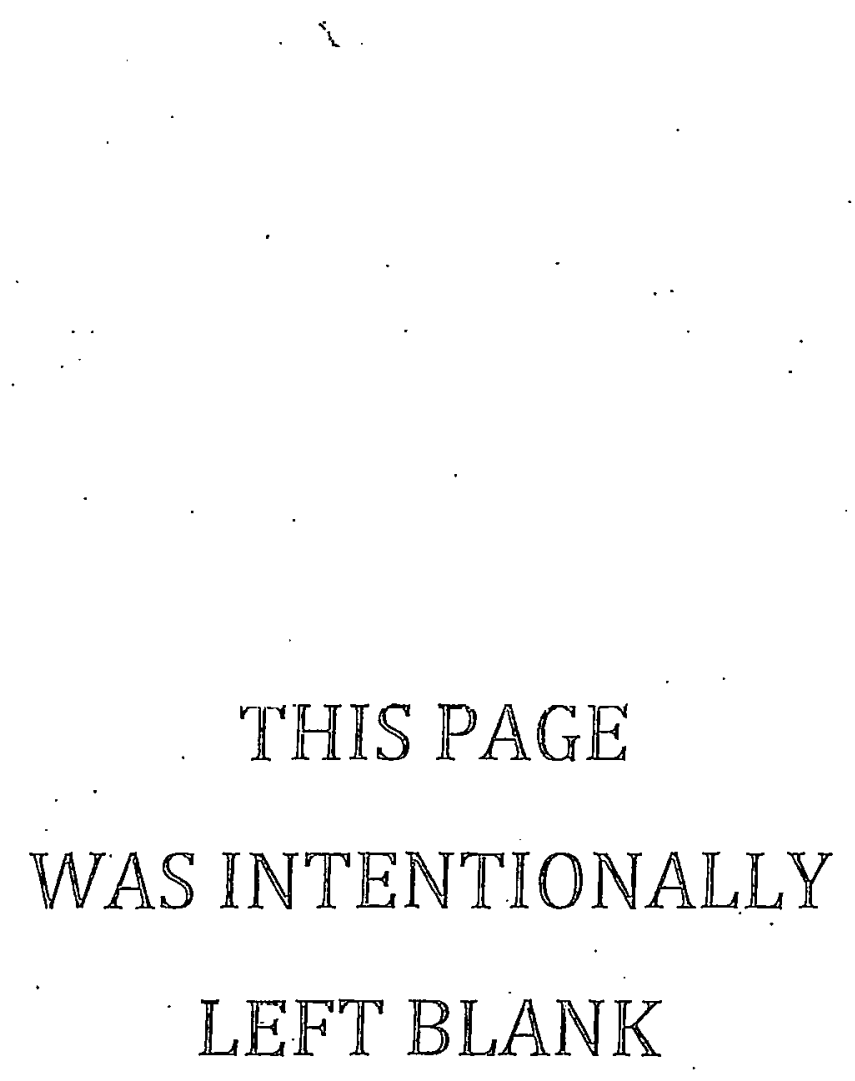




\section{TABLB OP CONTENTS}

$\underline{\text { Page }}$

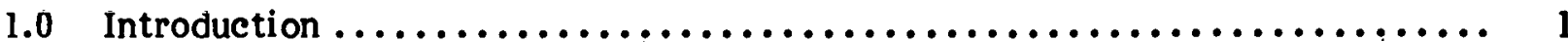

2.0 Solar Technology for Process Heat......................... 3

3.0 Review of Cost and Performance of Solar IPH System ............... 7

4.0 Prospects for Solar IPH $\ldots \ldots \ldots \ldots \ldots \ldots \ldots \ldots \ldots \ldots \ldots \ldots \ldots \ldots \ldots \ldots \ldots \ldots$

5.0 Federal Policy and the Prospects for Solar IPH $\ldots \ldots \ldots \ldots \ldots \ldots \ldots \ldots \ldots \ldots$

6.0 Conclusions $\ldots \ldots \ldots \ldots \ldots \ldots \ldots \ldots \ldots \ldots \ldots \ldots \ldots \ldots \ldots \ldots \ldots \ldots \ldots \ldots$

7.0 Bibliography $\ldots \ldots \ldots \ldots \ldots \ldots \ldots \ldots \ldots \ldots \ldots \ldots \ldots \ldots \ldots \ldots \ldots \ldots \ldots \ldots \ldots$ 
‘

\section{THIS PAGE}

\section{WAS INTENTIONALLY LEFT BLANK}




\section{LST OP PIGURES}

$\underline{\text { Page }}$

1 Distribution of Industrial Process Heat Demand by Temperature Range (1974) .................................... 3

2 Practical Operating Temperature Ranges of Several Types of Solar Thermal.Collectors for Industrial Process Heat ....................

3 DOE Solar Thermal IPH Field Experiments..................... 5

4 Effect of Investment Tax Credit on the Break-Even Price of Displaced Fossil Fuel ................................ 14

5 Effect of Amortization Life on the Break-Even Price of Displaced Fossil Fuel ....................................... 15

\section{LIST OF TABLES}

1 Cost and Performance of Solar Thermal IPH Systems.

2 Predicted Cost and Performance of Proposed Solar Thermal IPH Systems . 


\section{SECTION 1}

\section{INTRODUCTION}

In a recent publication by the Harvard Business School, the attitude of industry toward production costs, and especially toward those costs associated with energy supply, is summarized in the following statement: "Incustry is characterized by constant selfawareness. Ever greater eff ort goes into computing and comparing in order to better allocate resources, balance processes and improve products. Industry has a bottom line, and profits are its final test" (Stobaugh 1979). Indeed, as rapidly rising energy costs put a squeeze on profits, most industries have posted an enviable record in reduction of energy consumption.* While not every corporation can afford to be innovative, a significant number of corporations still find the resources to support the research and development necessary to alter energy consumption in production processes or to change the source of energy supply to those processes. This generally innovative attitude makes industry a fertile ground for the introduction of new energy supply technologies, such as solar energy.

From the perspective of the solar energy research community, industry has become an important focal area for one major reason: sheer size of demand. Manufacturing accounts for approximately $35 \%$ of the end-use demand for energy in the United States (1978)-a share which is nearly equal to total residential and commercial energy use and 1.3 times the total energy demand for transportation** (EIA 1980). The Department of Energy regards the possibility of displacing fossil fuel as a primary argument in favor of solar energy; the large demand of the industrial sector supports an emphasis on solar industrial applications. Potential solar supply to industrial energy needs could come in a variety of ways. For example, the term "solar energy" encompasses not only the direct use of the thermal energy of the sun, but also the direct use of photoelectric energy through solar cells and the indirect use of solar energy in the form of biomass or wind. These solar energy forms could supply industrial energy not only as heat, but as electric power, mechanical power, or synthetic fuels and feedstocks. Although certain technologies, such as biomass, have the potential for much broader and more significant impact than others, all may have applicability, separately or together, in specific markets.

Attention in this paper is devoted to direct solar thermal technologies and their application to industrial process heat. While solar thermal applications are certainly not the only feasible options being explored by industry and the government today, this program is perhaps the most active element of the federal industrial solar program and one for which at least preliminary results in actual field tests are available. The federal government is sponsoring an active program in the analysis and demonstration of this technology for industry in an attempt to move it from familiar and accepted ground in

*According to Energy magazine, 3 April 1978; U.S. manufacturing concerns reduced energy consumption per dollar of value added by an average of $26 \%$ from 1971 to 1976 (P. 8).

**According to the Energy Information Administration (EIA), industry (including agriculture, mining, and heavy construction) consumed 29.247 quads ( $10^{15} \mathrm{Btu}$ ) of primary energy in 1978. Approximately 22.6 quads were consumed directly in manufacturing industries, SIC codes 20 to 39 . Residential and commercial consumption was 28.582 quads and transportation consumption 20.614 quads, for a total of 78.443 quads consumed in the U.S during 1978 . 
residential use into the relatively untested territory of industry. An examination of past progress provides a worthwhile example of the many problems that will be encountered in the introduction of new technology to the industrial energy marketplace. 


\section{SECTION 2.0}

\section{SOLAR TECHNOLOGY POR PROCESS HEAT}

The efficiency of solar thermal collectors depends to a large extent on the temperatures of heat output required. Industrial process heat (referred to here as IPH) accounts for approximately half of manuf acturing energy end-use demand and is required over a wide range of output temperatures, as shown in Fig. 1 (InterTechnology 1977). Therefore, although a large variety of solar thermal technologies are theoretically suitable for IPH, only certain technologies off er conversion efficiencies high enough to be commercially viable. Many of these collector technologies have been field-tested in residential, commercial, or industrial settings; others are still under development in laboratories throughout the United States. As noted in Fig. 2, the practical ranges of operating temperatures have considerable overlap. The choice of a particular solar collector and heat transf er system from these overlapping operating ranges depends on local climatic conditions, process requirements, and of course, cost.*

\section{Figure 1. Distribution of Industrial Process Heat Demand by Temperature Range (1974)}

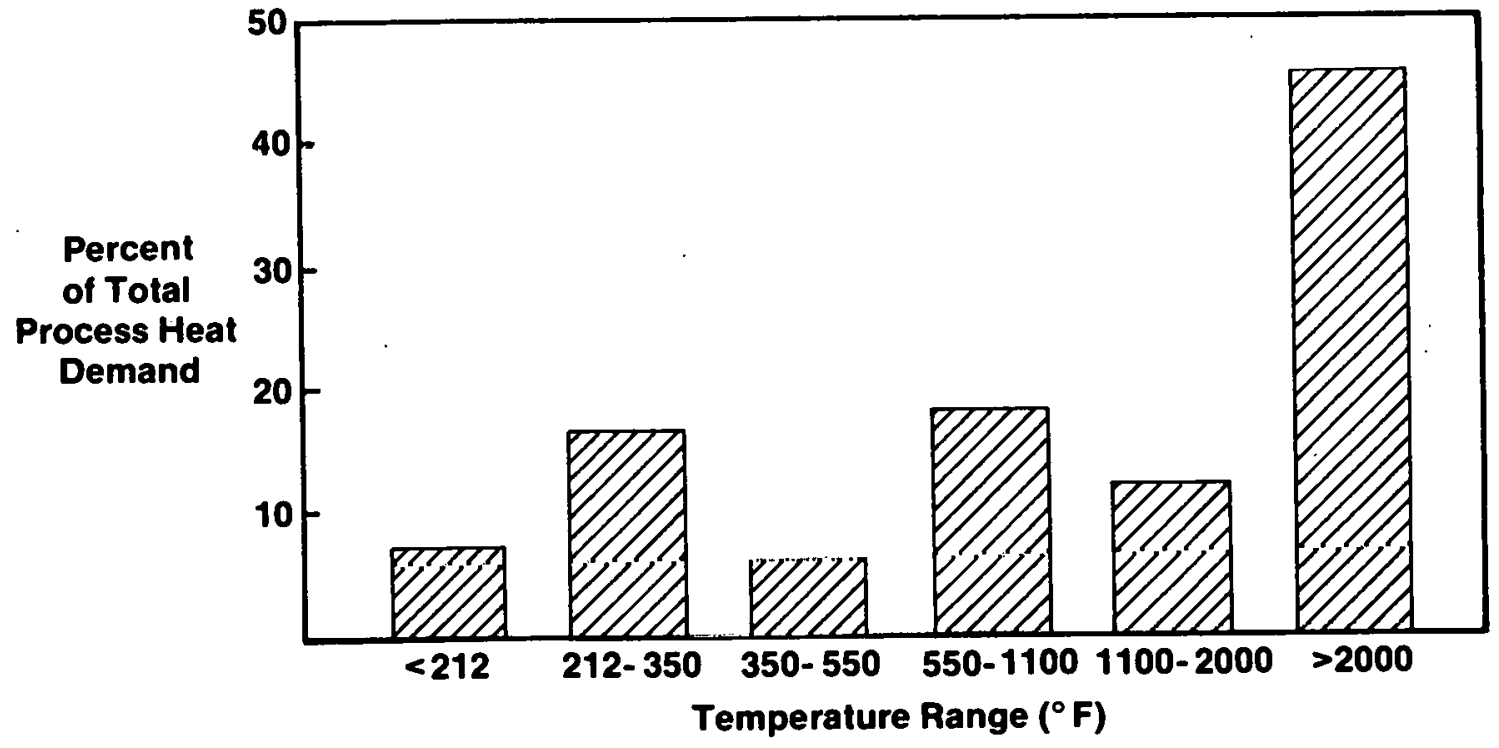

Source: InterTechnology, 1977.

*A computerized routine for comparison and selection of appropriate solar collectors and heat transfer systems on the basis of these conditions has been developed at the Solar Energy Research Institute (SERI). The computer program is known as PROSYS/ECONMAT and is described in SERI/TR-34-09 1, End-Use Matching for Solar Industrial Process Heat. 


\section{Figure 2. Practical Operating Temperature Ranges of Several Types of Solar Thermal Collectors for Industrial Process Heat}

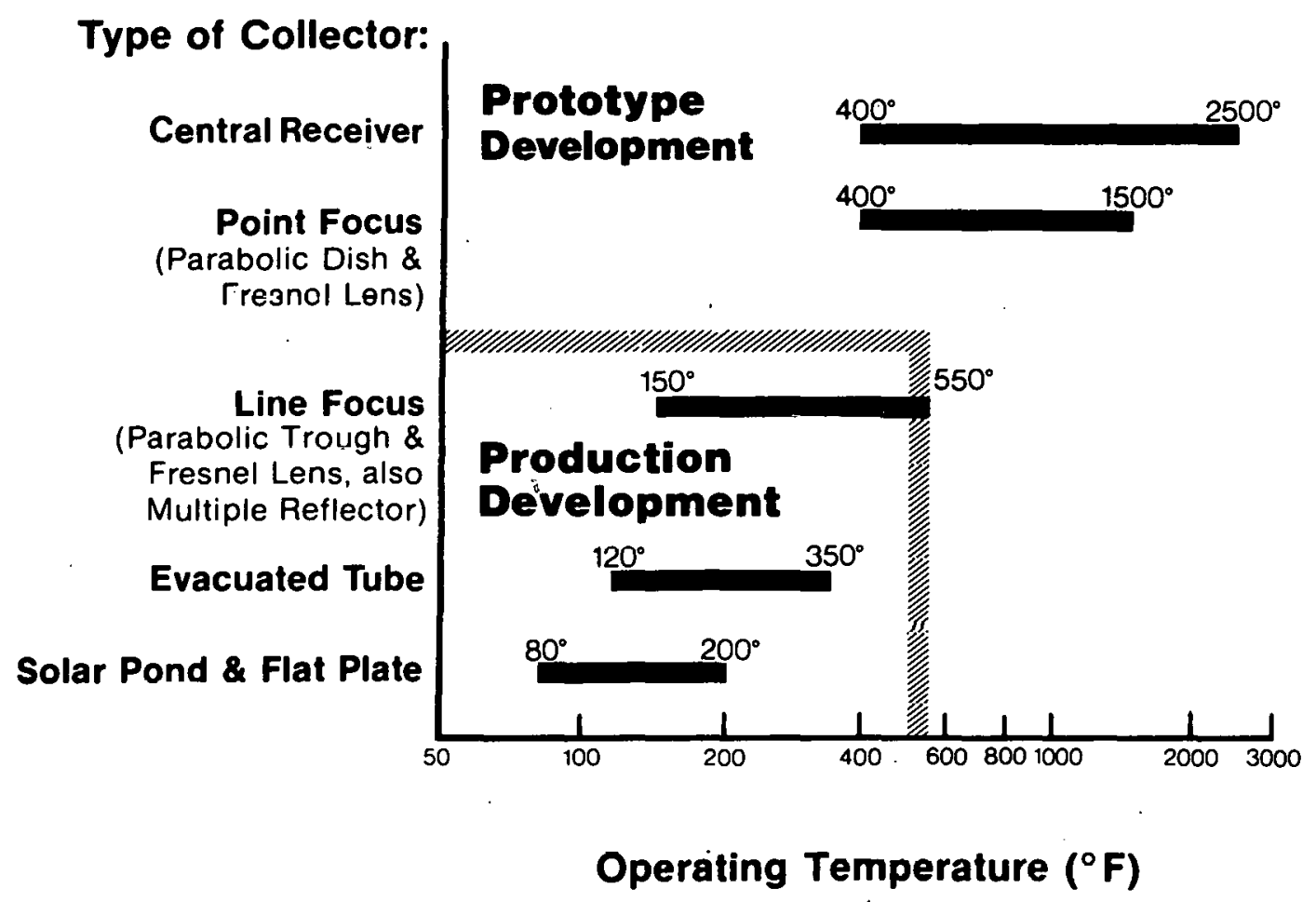

Collestor terhnologies may be conveniently alvided into four categories, based on optical sharacteristics. Nontracking, nonconcentrating colleetui's (almost cxclueively comprisen of the so-called flat-plate collector) have lie broadest baco of installatinn and development history. Over 80,000 active solar heating, cooling, or hot water systems have been installed in residential or commercial facilities across the U.S., and most rely on flatplate solar collectors. Nearly 50,000 sq. ft. of flat-plate collectors have been installed at six sites for industrial applications. In all, nearly 12 million sq. $\mathrm{ft}$. of medium temperature collectors have been shipped by domestic producers since 1974 (Bureau of the Census 1980).* Nontracking, semiconcentrating technology is typified by the evacuated tube collector in connection with either cusp or V-trough reflector backings. These collectors appear to be gaining more favor among plant engineers for their ability to obtain output temperatures higher than the traditional flat-plate collector (up to $350^{\circ} \mathrm{F}$ ) while maintaining the simplicity of a fixed mounting. The third major category is the linefocusing, tracking collector. Several variations of line-focusing technology have been proposed; nearly all are capable of extended operation at output temperatures of approximately $500^{\circ} \mathrm{F}$. The parabolic trough collector, in which optical concentration ratios of

* Despite the volume of this production, there are still significant engineering problems to be overcome in flat-plate collector installations. See, for example, remarks by HUD official Joseph Sherman in the Solar Energy Intelligence Report, Vol. 6, No. 8, 25 February 1980 , p. 71 . 
50 or more can be obtained, is the most commonly used device. Over 39,000 sq. ft. of parabolic trough collectors have been installed for industrial use since 1977.

Laboratory and pilot development of tracking, point-focusing collector technology is bringing these technologies to the verge of industrial deployment. Two major categories of point-focusing technology have been developed: (1) the distributed parabolic dish and (2) the central receiver. These collector technologies, because of their ability to provide concentration ratios of up to 1000 , are able to produce temperatures in excess $02^{\circ} \mathrm{F}$.

The solar collector array acts as a heat source for energy delivery systems tailored to particular process needs. For example, by circulating heat transfer fluids through the collector array (including ethylene glycol/water solutions at low temperatures or commercial heat transfer oils at higher temperatures), industrial hot water, hot air, or industrial steam may be provided via heat exchangers. Occasionally, it may be appropriate to substitute oil heated directly in the array for heat transfer oils heated in process furnaces. Alternatively, water or air may be heated directly in certain types of solar collector arrays and used in the process. Although these "direct" systems off er the highest possible efficiencies, they are of ten impossible to implement because of the standards of purity of the industry in question (e.g., food processing) or because of inherent difficulties with freezing and storage. Steam may also be produced directly in solar collector arrays by flashing water to steam or by direct boiling (as in central receiver technology).

Nearly every system and collector concept is represented in the Department of Energy's fi eld engineering test program. Rather than pursue an exhaustive theoretical discussion of these concepts, this paper concentrates on a discussion of the particular system concepts and applications contained in the federal program.

The Department of Energy has sponsored the design, and in some cases construction and operation, of 18 solar industrial process heat projects since 1975 (see Fig. 3). Eleven of

\section{Figure 3. DOE Solar Thermal}
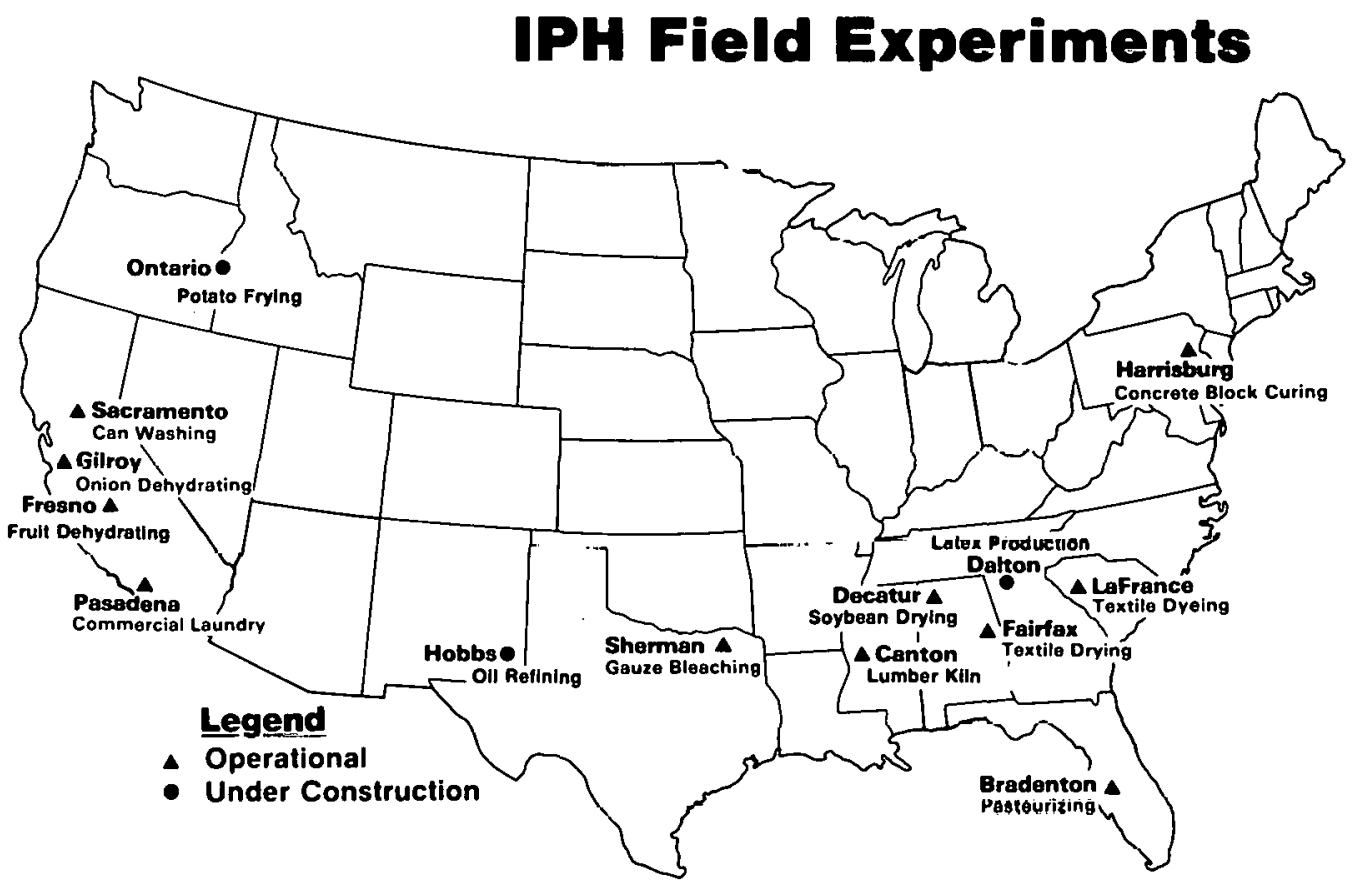
these projects are now operating; six have been operating for at least one year. Three more projects to provide solar-generated process steam are under construction and will be operational in 1981 . In addition, conceptual designs have been initiated for other large-scale steam systems and soon will be begun for several large-scale hot water systems. These field projects represent the state of the art in collector equipment and in system design. It is instructive to review their status as an indicator of present trends. 


\section{SECTION 3.0}

\section{REVIEW OF COST AND PERFORMANCE OF SOLAR IPH SYSTEMS}

By and large, solar IPH systems will supplement existing heating systems by displacing fossil fuels. Although energy storage has been incorporated into several of the current dem onstration systems, each retains a full-capacity fossil fuel backup. As a result, the success of solar IPH systems is measured by annual fuel savings, which are directly proportional to the energy delivery capacity and utilization of the solar system. The energy delivery capacity of solar IPH systems designed in the DOE program vary from a predicted high of $370,000 \mathrm{Btu} /$ year per square foot of collector aperture area to a low of $110,000 \mathrm{Btu} / \mathrm{yr}$ (see Table 1). This predicted delivered energy capacity is based on $100 \%$ utilization of the solar system; that is, solar heat from the collector array was assumed to be usefully absorbed by the process at all times that the system was operating. Actual experience with the operating demonstrations shows that full utilization is inf requent. This lack of utilization, along with unexpected inefficiencies in the delivery system and in the collector array, led to lower annual outputs than predicted in design. As shown in Table 1, the actual annual energy capacity varied from a high of $148,000 \mathrm{Btu} / \mathrm{yr}$ per square foot to a low of $35,000 \mathrm{Btu} / \mathrm{yr}$ per square foot for the five systems for which operating data is available.

Because the energy delivery of a solar thermal IPH system is calculated with respect to actual delivered heat at the point of use, a solar system providing one Btu of energy actually displaces more than one Btu of fuel equivalent. The efficiency of conversion of the solar system is implicitly contained in the energy delivery figures given; the efficiency of fuel conversion (which may vary from $65 \%$ to $85 \%$ in conventional boilers and furnaces) is of ten not included in calculating fossil energy displacement. The fuel savings of a solar system, then, are equal to the annual energy capacity of the system divided by the conventional fossil fuel conversion efficiency.

The costs of solar IPH systems have varied considerably with respect to location, collector type, and auxiliary system construction requirements. Design costs of IPH systems are shown in Table 1, along with actual costs incurred in six completed projects. Although capital costs in terms of dollars per square foot are commonly quoted, these units can be somewhat misleading. To show costs that are related to units of energy capacity, the capital costs of the systems are also shown in dollars per million Btu per year of nominal output. [This unit, similar to cost units of $\$ / \mathrm{kW}$, or $\$ /(\mathrm{MBtu} / \mathrm{h})$, is adopted for convenience in calculating levelized solar costs and for consistency with normal conventional practices; throughout the paper the unit will be referred to as energy capacity cost and written as $\$ /(\mathrm{MBtu} / \mathrm{yr})]$. Note that the costs vary from a low of $108 \$ /(\mathrm{MBtu} / \mathrm{yr})$ to a high of $536 \$ /(\mathrm{MBtu} / \mathrm{yr})$ on a predicted performance basis. The average cost, exclusive of the highest and lowest costs given, is $276 \$ /(\mathrm{MBtu} / \mathrm{yr})$. Assuming that simple, af ter-tax payback periods of three to five years will be required of energy saving investments, one finds that the break-even market price of the displaced fuel would have to be between $\$ 94$ and $\$ 52$ per million Btu to justify a solar investment at this average cost.*

*Break-even fuel costs have been calculated on the basis of a simple (undiscounted) payback formula that takes into account tax effects (see Dickinson 1979, p. 25). Straight line depreciation over 10 years was assumed, annual operating and maintenance costs were taken as $3 \%$ of initial capital cost, an investment tax credit of $20 \%$ was used, an effective total tax rate of $50 \%$ taken, and displacement of fuel used at $70 \%$ efficiency was 
Tabla 1. COST AND PERFORMANCE OF SOLAR THERMAL IPH SYSTEMS

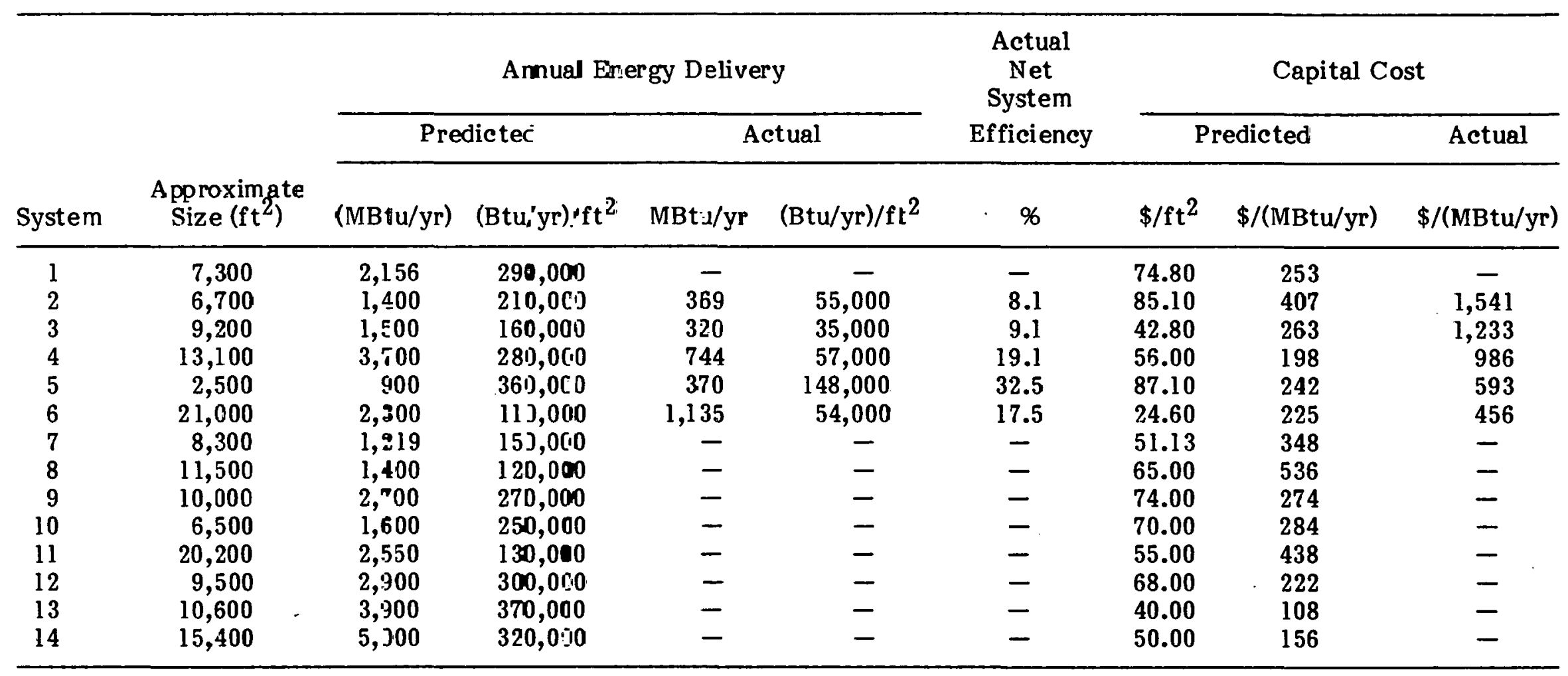

Source: Kutscher and Davenport (1980) and internal records. 
Even with a ten-year payback allowed, the break-even cost would be $\$ 20 / \mathrm{MBt}$, or nearly $\$ 120$ per barrel of oil. Obviously, at such costs, solar IPH systems are not competitive.

More recent cost projections have been made for proposed solar industrial process heat systems that have an average predicted capacity cost somewhat less than 276 $\$ /(\mathrm{MBtu} / \mathrm{yr})$. Proposed solar industrial process heat projects, including cost information where available, are shown in Table 2. The average capacity cost for these proposed projeets is about $160 \$ /(\mathrm{MBtu} / \mathrm{yr}$ ). Break-even fuel costs would vary between $\$ 54 / \mathrm{MBtu}$ (or about $\$ 325 / \mathrm{bbl}$ of oil equivalent) for 3 -year payback to $\$ 12 / \mathrm{MBtu}$ (or about $\$ 72 / \mathrm{bbl}$ of oil) for a 10-year payback. If a 10-year payback were acceptable, then it is possible that certain companies paying for fuel purchased at or near marginal world oil prices (currently around $\$ 42 / \mathrm{bbl}$ ) would find solar supplement to process heat an acceptable investment.

Unfortunately, the poor performance of the field experiments described in Table 1 actually diminishes the prospects of economic competitiveness in the near term. When actual operating annual output is folded into the calculation of capital cost for capacity, the average cost is $962 \$ /(\mathrm{MBtu} / \mathrm{yr})$. Hence, the break-even equivalent oil cost is over three times higher, or approximately $\$ 460$ per barrel. Two conclusions are obvious: first, actual obtained perf orm ance of solar IPH systems must improve dramatically; and second, installed costs must be reduced in a commensurate fashion. Durability and reliability require far more demonstration, of course, but it is clear that without significant general improvement in cost effectiveness, solar IPH will hardly offer an attractive opportunity for industrial capital. The remainder of this paper describes the actions that are being taken, or must be taken, in order to make solar IPH a viable investment.

Table 2. PREDICTED COST AND PERFORMANCE OF PROPOSED SOLAR THERMAL IPH SYSTEMS

\begin{tabular}{cccc}
\hline Systcm & $\begin{array}{c}\text { Approximate } \\
\text { Size }\left(\mathrm{ft}^{2}\right)\end{array}$ & $\begin{array}{c}\text { Annual Energy Delivery } \\
(\mathrm{MBtu} / \mathrm{yr})\end{array}$ & $\begin{array}{r}\text { Capital Cost } \\
\$ /(\mathrm{MBtu} / \mathrm{yr})\end{array}$ \\
\hline 1 & & 20,000 & 147 \\
2 & & 9,000 & 219 \\
3 & $\leqslant 50,000$ & 24,000 & 100 \\
4 & & 12,600 & 209 \\
5 & & 14,700 & 152 \\
6 & & 8,760 & 155 \\
7 & 237,900 & 17,500 & 144 \\
8 & 171,300 & 118,700 & - \\
9 & 671,000 & 70,400 & - \\
10 & 210,000 & 339,000 & - \\
11 & 179,200 & \\
\hline
\end{tabular}


SEPI 


\section{SECTION 4.0}

\section{PROSPECTS FOR SOLAR IPH}

Successful implementation of solar thermal systems in industry will depend upon an attack on at least three fronts. First, the cost and performance of solar thermal systems for IPH must be improved substantially. Second, the most appropriate and advantageous applications for this technology must be located and developed. And third, the government, if it decides involvement is warranted, should act to encourage implementation through the various instruments of policy at its disposal. The successful introduction of a new technology into the industrial marketplace must follow those attacks in sequence. In other words, primary emphasis must be placed on obtaining a viable technology. Government incentives or market development can make no headway without a viable product.

To obtain the cost and performance improvements necessary to promote solar technology as a viable investment, it is first important to establish exactly what performance and cost improvements are required to be cost-competitive: cost and performance goals must be established. There are obvious physical limitations to performance improvement; the efficiency of a solar thermal system cannot exceed $100 \%$. What average annual efficiency can ultimately be obtained is the subject of a great deal of research at the present time. According to scientists at the Solar Energy Research Institute, physical limitations of the properties of reflective materials, glass, heat transfer media, and insulation will probably limit solar system average annual efficiency at intermediate temperatures to approximately $60 \%$. This $60 \%$ limit should be considered as an ultimate goal, approachable only with extremely precise control, high-quality materials, and efficient system design and operation. Cost limits for the solar thermal systems are more difficult to define, except that, of course, the cost of the system may not be zero. A possible lower limit on the cost of solar systems, based on basic materials and land costs, is $\$ 10 / \mathrm{ft}^{2}$.

The combination of cost and performance is embodied in the energy capacity cost of solar IPH systems, expressed as $\$ /(\mathrm{MBtu} / \mathrm{yr})$. Assuming that at least a 3-year payback will be required of energy-related investments in the future,* and that alternative fuels will be available at or below the current marginal cost of crude oil, the appropriate solar cost/performance goal may be calculated. Hence, for an alternative fuel price of $\$ 7 / \mathrm{MBtu}$ and a fossil fuel conversion efficiency of $70 \%$, solar thermal IPH systems must not exceed an energy capacity cost of $20.62 \$ /(\mathrm{MBtu} / \mathrm{yr})$. If the best possible solar system efficiency were obtained and the best possible location was available (for example, El Paso, Texas) the annual delivered energy would be $0.60 \times 840,000\left(\mathrm{Btu} / \mathrm{ft}^{2}\right) / \mathrm{yr}=$ $504,000\left(\mathrm{Btu} / \mathrm{ft}^{2}\right) / \mathrm{yr}$. In order to meet a goal of $20.62 \$ /(\mathrm{MBtu} / \mathrm{yr})$, the system would have to be installed at less than $\$ 10.40$ per square foot of collector aperture area. Considering that the average cost of installed systems in Table 1 is about $\$ 61 / \mathrm{ft}^{2}$, the challenge represented by this goal is significant.

*In interviews conducted by consultants for the Southern California Gas Company during 1977 , it was found that a number of companies were willing to consider 5-year payback periods on energy-related investments. If a 5-year payback is assumed in the above calculations, the required installed system cost must be no greater than about $\$ 19.00$ per square foot. 
In addition to the obvious need for system cost reduction and better output performance, solar thermal technology is in need of improved durability and reliability. In many cases, simple improvements in engineering practice will result in better IPH systems. In others, more basic collector or component improvements are needed.

Since one is faced with such distant prospects of widespread cost-competiveness of solar process heat, any near-term implementation of this technology is crucially dependent on the choice of application. Not every industrial concern has the same outlook for fossil fuel availability or price. In certain situations, the actual cost of fuel may be much higher or much lower than the $\$ 7 / \mathrm{MBtu}$ assumed above. In addition, some industrial processes are more physically compatible with solar thermal heat (and the way in which it may be supplied) than others. Recent investigations at the Solar Energy Research Institute indicate that solar energy is most suited to applications which have most, or all, of the following properties:

(1) a location with high solar insolation and high ambient temperatures,

(2) a location with low air pollution levels so as not to degrade collector surfaces,

(3) a location where environmental standards or fuel regulation discourage or prohibit fossil fuel use,

(4) low temperature requirements in the process,

(5) continuous operations where temperature or heat rate control are not critical,

(6) buil t-in storage in the process,

(7) high and rapidly escalating fuel costs or inefficient fuel usage,

(8) uncertain fuel supplies and energy-intensive or -dependent processing, and

(9) available land or roof area and suitable plant layout to facilitate the addition of a solar system.

It is likely that the coincidence of all of these factors will be found only in a few isolated industrial plants. Certain industries, such as the food processing Industry, seem to pos. sess many of these important characteristics and may be the most likely initial markets for solar energy. However, spccifio processes and plant locations must be identified before the applicability of solar energy can be determined. The task is nearly impossible for solar equipment suppliers to complete; as a result, the identification of specific applications will depend to a great extent upon self-evaluation by plant engineers and managers. The ability of plant personnel to recognize good solar applications will, in turn, depend upon eff ective communication between solar research and development programs and the industrial community regarding the status and prospects for solar IPH. 


\section{SECTION 5.0}

\section{FEDERAL POLICY AND THE PROSPECTS FOR SOLAR IPH}

As stated earlier, it is important to recognize that government tax incentive and market development programs are ineffective without a viable technology base. Therefore, federal market stimulation is a final and indirect phase of government involvement and must be carefully scrutinized to ensure that such "benevolent" interference is efficient and productive. Perhaps the measure of that effectiveness should be the speed with which the government is able to withdraw from participation.

President Carter, on 20 June 1979, declared that $20 \%$ of domestic energy demand would be supplied by renewable resources in the year 2000, and that of that goal, $14 \%$ of the renewable energy (or 2.6 quads) would be provided in the incustrial and agricultural sector by solar thermal energy. At predicted output efficiencies, this goal would require the cumulative installation of somewhere between eight and ten billion square feet of solar collectors in industry, equivalent to a total capital expenditure of nearly $\$ 400$ billion. This goal is an ambitious one and undoubtedly will require a vigorous economic incentive program.

Federal economic incentives are most frequently associated with provisions for tax relief, since these are most of ten the most direct and unobtrusive means of conferring economic value upon selected classes of capital investment. Since 30 September 1978, an investment tax credit of $10 \%$ has been available (in addition to the standard 10\% capital equipment tax credit) for solar process heat equipment purchased by industry. Legislation sponsored by Senator Robert Packwood (Oregon) and Representative Wyche Fowler (Georgia) in 1979, sought to increase this additional tax credit to $40 \%$, thus making the total credit $50 \%$ for solar IPH investments. The final version of this proposal, agreed upon by a House-Senate conference committee on 11 February 1980, grants an additional $15 \%$ investment tax credit, for a total credit of $25 \%$ on solar systems purchased for industrial process heat. Three-year carryback and seven-year carryforward of the credit would be allowed* (SEIR 1980). As shown in Fig. 4, the effect of a $25 \%$ investment tax credit rather than the current $20 \%$ credit is so small as to be ineffective. The effect of a possible $50 \%$ investment tax credit is enough, however, to make solar IPH systems installed for $160 \$ /(\mathrm{MBtu} / \mathrm{yr})$ a competitive investment with ten-year payback where displaced fuel costs an average of $\$ 5 / \mathrm{MBtu}$.

The other major instrument of tax policy at the federal government's disposal is the definition and establishment of allowed depreciation, or tax, life. Currently, the minimum allowed depreciation period for capital equipment (in order to recover the full value of investment tax credits) is 7 years. Ordinarily, plant energy-related equipment (such as boilers and furnaces) have been allowed a depreciation life of between 15 and 23 years. In the previous calculations, a depreciation period of 10 years was assumed, because no specific rulings on solar IPH equipment have been made by the Internal Revenue Service and a shorter tax life is advantageous to capital-intensive investments. The effect of a decision by the government to allow a three-year (H.R. 5084), five-year, or seven-year amortization of solar investments is shown in Fig. 5.

*The solar tax incentive bill (H. R. 3919) was tied to the so-called "Windfall Profits Tax" bill and is to be funded through the expected revenues accruing from petroleum excise taxes. 


\section{Figure 4. Effect of Investment Tax Credit on the Break-Even Price of Displaced Fossil Fuel}

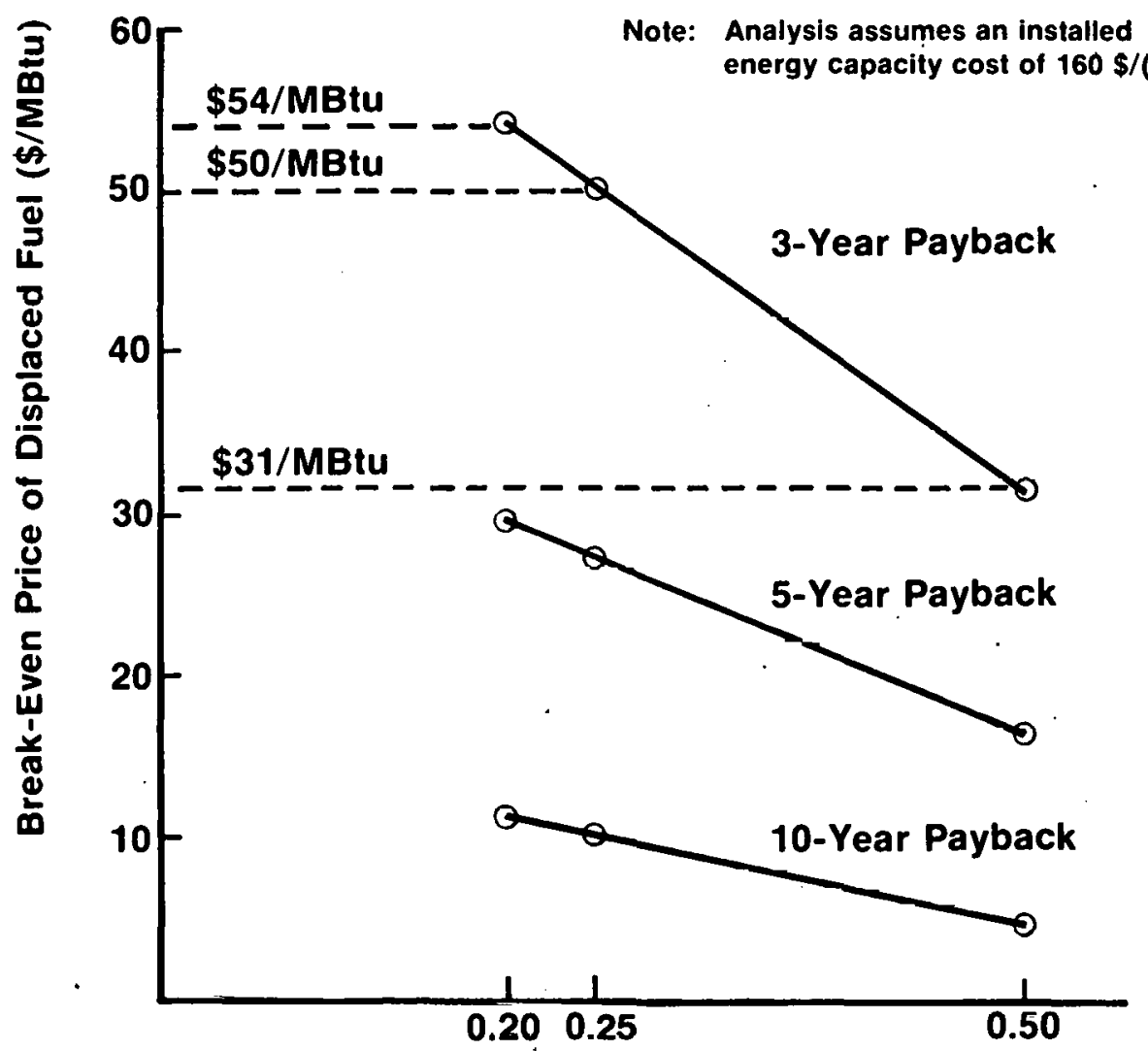

Thtal Investment Tax Credit

Despite the significant effects that massive federal tax incentives have on the breakcven prices of competing fuel for solar IPH, it is clear that investment will be limited by two major constraints. First, as mentioned beforé, solar IPH technology must demonstrate reliability and functional success over a suitable period of time and be adequately matched in physical capabilities to the task at hand. Second, industry must be able and willing to commit the capital required for the purchase of such systems. Manufacturing industries spent $\$ 109.4$ billion on gross capital investment in 1978 (Industry and Trade Administration 1980). Energy-related investment rurely exceeds $25 \%$ of the total annual capital expenditure of industry in a given year, so that, at most, about $\$ 25$ billion was spent on energy equipment in 1978 . If only $1 \%$ of the energy consumed by the manufacturing sector for process heat in 1978 (approximately 0.1 quad) were provided by solar energy in that year, the capital investment required would have been at least $\$ 15$ billion [assuming solar could be installed at the optimistic cost of 150 $\$ /(\mathrm{MBtu} / \mathrm{yr})]$. That is, to supplant $1 \%$ of the process energy use of industry, an investment of at least $60 \%$ of the actual planned total energy-related expenditure in that year would have been required. This severe capital strain suggests two concerns. First, the commitment of large amounts of capital to renewable energy equipment will depend 


\section{Figure 5. Effect of Amortization Life on the Break-Even Price of Displaced Fossil Fuel}

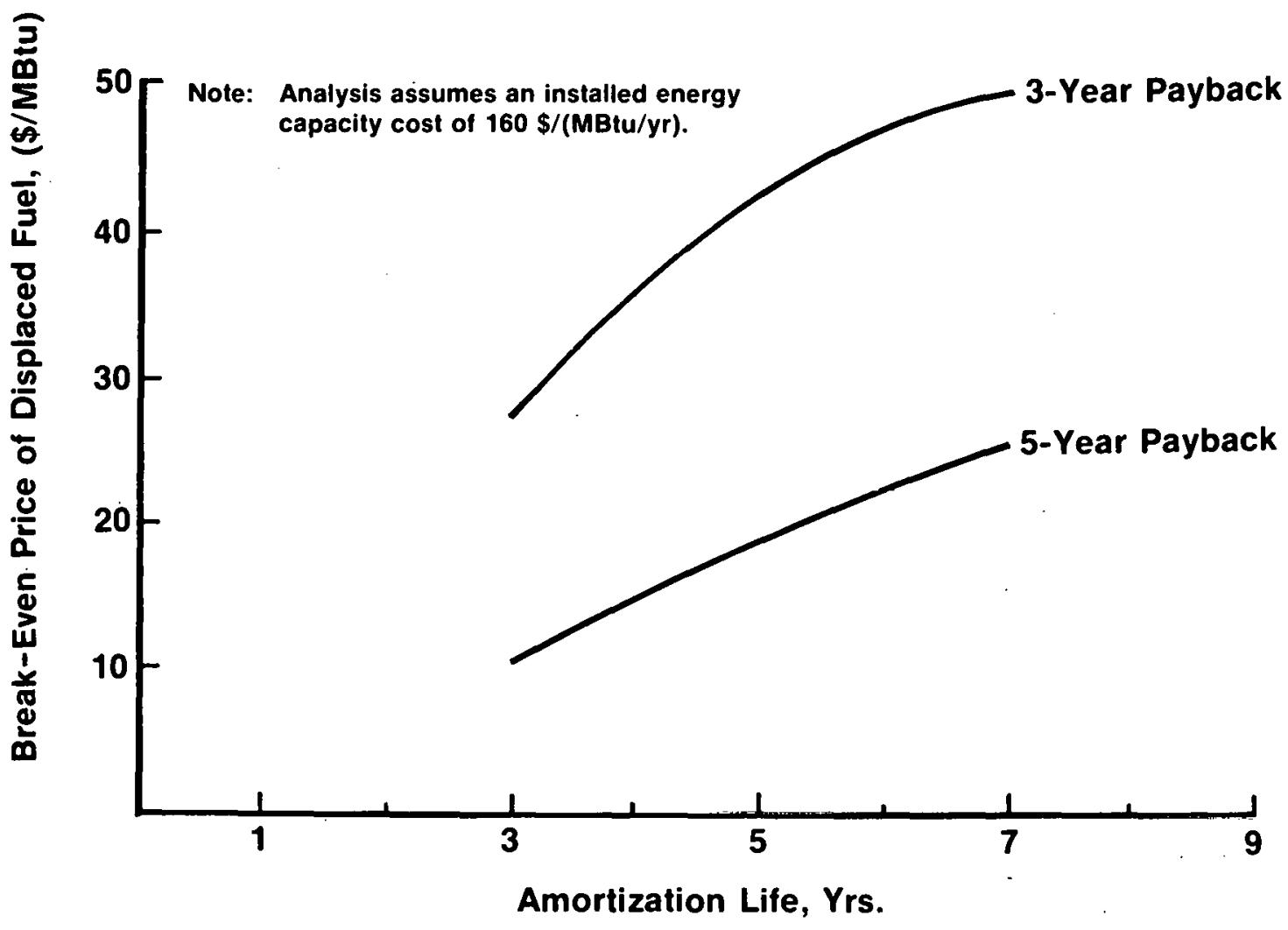

heavily upon the relative importance of energy as a factor in production for the industry concerned. For example, the likelihood of significant solar investment by apparel manufacturers (SIC 23), where energy cost is only $0.7 \%$ of the value of shipments, is not large. The likelihood of such an investment by organic fiber manufacturers (SIC 2824), where energy costs are $24.5 \%$ of the value of shipments, is much greater. A second concern, even for industries facing high energy costs, is simply the availability of desired capital. It is in this area that the federal government, through the indirect support of capital formation in the financial network or through financing guarantees or federal loan banks, may have some eff ect. 


\section{SEPI}




\section{SECTION 6.0}

\section{CONCLUSIONS}

Government policies can have a significant impact on the calculated economics of solar investments. However, tax benefits are never a substitute for reliable and efficient system performance. It is clear. that although solar thermal systems for industry exhibit significant fuel savings potential and might contribute significantly to national goals of energy self-sufficiency, the current state of solar thermal technology leaves most of this potential unrealized. More experience must be gained with operating systems in industrial environments and advances in technology must be sought in order to improve both cost and performance. Industry's bottom line is profit, and profit depends on successful operation at minimum cost. Solar energy must prove itself against these criteria. If proven, the important intangible benefits of improved industrial energy efficiency and enhanced national energy security will provide a more suitable and stable business climate for United States industry. 


\section{S=PI战}




\section{SECTON 7.0}

\section{BIBLIOGRAPHY}

Bureau of the Census 1980. Statistical Abstract of the United States, 1979 Edition. Washington, DC: U.S. Department of Commerce. Table No. 1041.

Dickinson, W. C. and Brown, K. C. 1979. Economic Analysis of Solar Industrial Process Heat Systems: A Methodology to Determine Annual Required Revenue and Internal Rate of Return. UCRL-52814. Livermore, CA: Lawrence Livermore Laboratory. 17 August.

Energy Information Administration (EIA). 1980. Monthly Energy Review. DOE/EIA 0035/01 (80). Washing ton, DC: U.S. Departm ent of Energy. January.

Industry and Trade Administration. 1980. 1980 U.S. Industrial Outlook. Washington, DC: U.S. Department of Commerce. January.

InterTechnology. 1977. Analysis of the Economic Potential of Solar Thermal Energy to Provide Industrial Process Heat. No. 00028. Warrenton, VA: InterTechnology Corp. February.

Kutscher, C. and Davenport, R. 1980. Performance Results and Experience of the Operational Industrial Process Heat Field Tests. SERI/TR-333-385. Golden, CO: Solar Energy Research Institute.

Solar Energy Intelligence Report (SEIR). 1980. "Solar Process Heat Eligible for 15\% Credit." Solar Energy Intelligence Report. Vol. 6, No. 8, 25 February; p. 73.

Stobaugh, R. and Yergin, D., eds. 1979. Energy Future. New York: Random House p. 153 . 
SEPI* 


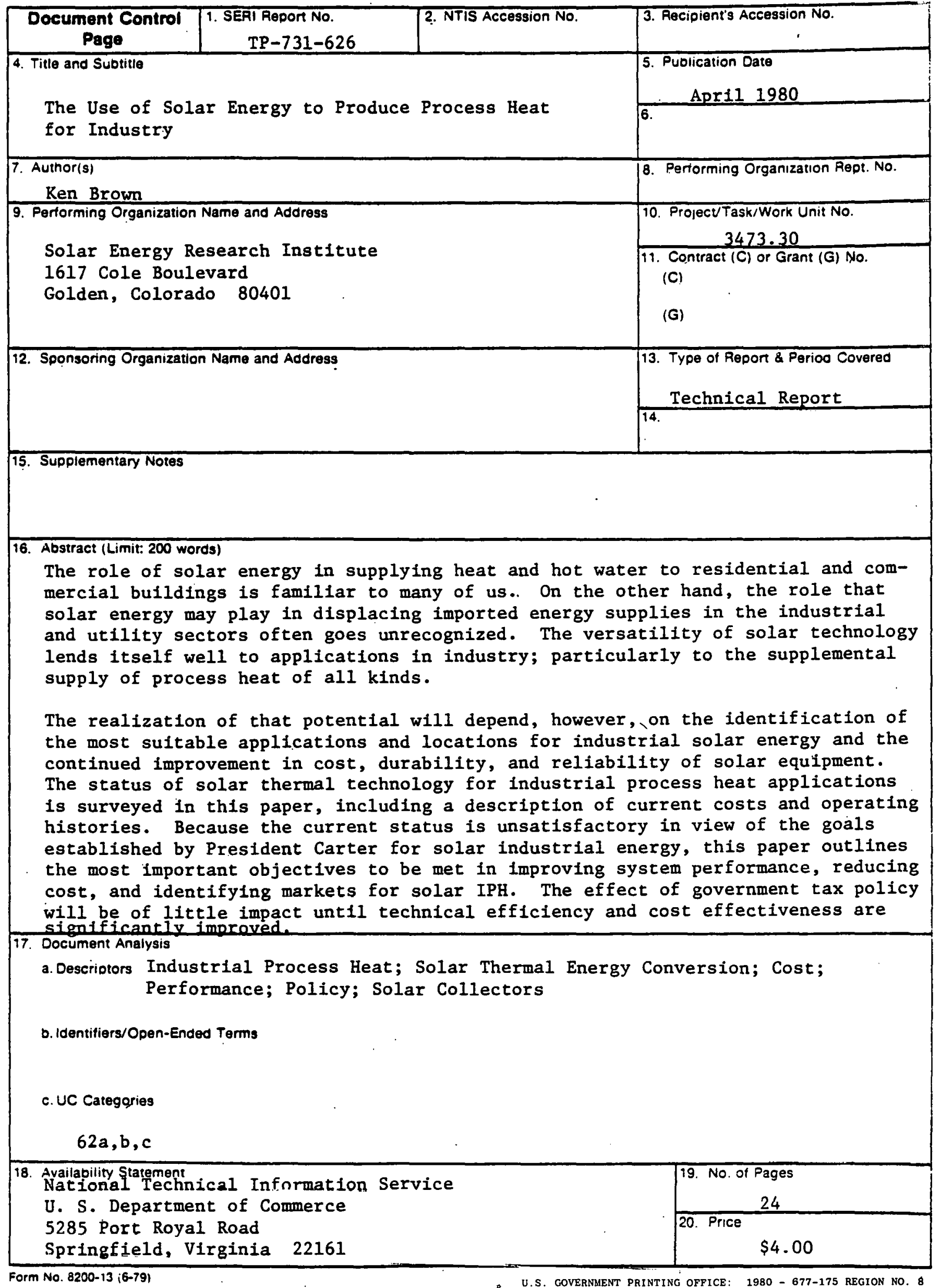

